\title{
Discussion on Planning and Design of Rural Tourism Landscape
}

\author{
Haoran Du \\ Huanghe Science and Technology College \\ Zhengzhou, China
}

\begin{abstract}
Rural tourism industry is in rapid development stage. As principal part of rural tourism, rural landscape plays a vital role in its development. Systematically analyze planning and design of rural tourism landscape, summarize problems existing in planning and design of rural tourism landscape of our country at the present stage, discuss how to effectively design the landscape according to rural environment, and then better promote the development of rural tourism industry.
\end{abstract}

Keywords $\rightarrow$ rural tourism; rural landscape; landscape planning and design

\section{INTRODUCTION}

In recent years, living standard of people becomes increasingly high. Construction of new countryside also moves forward continuously. As a new fashionable highlight, rural tourism grows unceasingly and becomes more and more popular among people. It becomes new economic growth point and important entry point to construct "beautiful China". Besides, rural tourism meets travel demands of people at present to get close to nature. Therefore, it receives extensive attention and promotion and shows enormous development prospect. As principal part of rural tourism, rural landscape also changes on pattern and content. However, at present, in common rural tourism planning, people pay more attention to rural tourism products and market development and think little of rural landscape. Under the background of rapid development of rural tourism, it has become key problem of rural tourism value development and sustainable development of rural tourism on how to keep rural landscape pattern rural and characteristic.

\section{INTRODUCTION TO RURAL TOURISM LANDSCAPE RESEARCH}

\section{A. Rural Landscape and Rural Tourism}

Rural landscape is a regional landscape complex formed on the basis of agricultural activities. It has specific landscape behavior, form, connotation and process. The settlement pattern changes from scattered farmhouse to town with the function of providing production and service for life. The landscape region has extensive land use, small population density, obvious rural characteristics and spatial feature of large dispersion and small concentration. [1] Rural landscape is "agricultural production landscape" and "landscape of farmers' living" that integrate natural conditions of land, production and life. Rural tourism takes rural community as activity site and has the characteristics of experiencing farming culture and local tradition. In reality, the appeal of rural tourism can be understood as rural image in general. The appearance performance of rural image is rural landscape. [2] Rural tourism bases on multiple characteristics of rural landscape. Close relationship exists between them. Rural landscape provides necessary environment of appreciation and experience for rural tourism, which provides new development pattern for rural landscape. Different rural landscape types and corresponding rural tourism types are showed in "Table I".

TABLE I. RURAL LANDSCAPE AND RURAL TOURISM

\begin{tabular}{|c|c|c|c|}
\hline $\begin{array}{c}\text { Rural } \\
\text { landscape } \\
\text { types }\end{array}$ & $\begin{array}{c}\text { Main } \\
\text { landscape }\end{array}$ & $\begin{array}{l}\text { Rural tourism } \\
\text { types }\end{array}$ & $\begin{array}{l}\text { Sightseeing activities } \\
\text { and experience forms }\end{array}$ \\
\hline $\begin{array}{l}\text { Natural } \\
\text { landscape }\end{array}$ & $\begin{array}{l}\text { Rural natural } \\
\text { scenery }\end{array}$ & $\begin{array}{l}\text { Rural landscape } \\
\text { scenery tour }\end{array}$ & $\begin{array}{l}\text { Mountaineering, forest } \\
\text { bathing, boating, skiing, } \\
\text { fishing }\end{array}$ \\
\hline $\begin{array}{l}\text { Agricultural } \\
\text { production } \\
\text { landscape }\end{array}$ & $\begin{array}{l}\text { Agricultural } \\
\text { landscape }\end{array}$ & $\begin{array}{l}\text { Sightseeing } \\
\text { agriculture tour, } \\
\text { agricultural } \\
\text { popular science } \\
\text { tour }\end{array}$ & $\begin{array}{l}\text { Agricultural sightseeing, } \\
\text { picking, breeding } \\
\text { experience, agricultural } \\
\text { science and technology } \\
\text { park/ expo park } \\
\text { sightseeing }\end{array}$ \\
\hline $\begin{array}{l}\text { Country } \\
\text { settlement } \\
\text { landscape }\end{array}$ & $\begin{array}{l}\text { Ancient } \\
\text { settlement }\end{array}$ & $\begin{array}{l}\text { Rural landscape } \\
\text { tour }\end{array}$ & $\begin{array}{ll}\text { Visit } & \text { villages, } \\
\text { characteristic } & \text { building } \\
\text { and courtyard, etc. }\end{array}$ \\
\hline $\begin{array}{l}\text { Historical } \\
\text { and cultural } \\
\text { landscape }\end{array}$ & $\begin{array}{l}\text { Historical } \\
\text { and cultural } \\
\text { sites, red } \\
\text { culture sites, } \\
\text { regional } \\
\text { historical } \\
\text { buildings }\end{array}$ & $\begin{array}{l}\text { Historical } \\
\text { culture tour }\end{array}$ & $\begin{array}{l}\text { Visit bulwark, fort } \\
\text { barbette, red culture } \\
\text { experience pavilion, } \\
\text { military camp and call- } \\
\text { officers-roll platform, } \\
\text { etc. }\end{array}$ \\
\hline $\begin{array}{l}\text { Rural } \\
\text { cultural } \\
\text { landscape }\end{array}$ & $\begin{array}{l}\text { Folk customs } \\
\text { village, local } \\
\text { custom relics }\end{array}$ & custom & $\begin{array}{l}\text { Farming show, folk } \\
\text { skill, folk costume, } \\
\text { civilian activities, folk } \\
\text { song and dance, cultural } \\
\text { relics, etc. }\end{array}$ \\
\hline
\end{tabular}

\section{B. Rural Tourism Landscape}

Rural tourism landscape refers to landscape resources that can serve as tourist attraction and change according to different regions and seasons in rural landscape, including natural tourism resources and humanistic tourism resources. [3] The uniqueness of rural tourism landscape lies in: Firstly, it is the landscape with purpose. The development foundation is 
natural and humanistic landscape resources in villages. The development aim is to strengthen appeal of villages for tourists; secondly, rural tourism landscape has very close relationship with industry. The planning and construction should closely connect with rural tourism industry and economic development level in villages; thirdly, rural tourism landscape focuses on rural industry landscape, natural ecological landscape and pastoral life landscape. The construction should coordinate with integrated planning of villages. [4]

Planning and design of rural tourism landscape should combine with new countryside planning and industry development, base on rural natural landscape resources, respect regional condition and local cultural characteristics of villages to organically combine and design village, farmland, road, river, pond, mountain land, forest land and culture.

\section{MAIN PROBLEMS EXISTING IN RURAL TOURISM LANDSCAPE}

In recent years, rural tourism industry develops very fast. Large quantities of villages have become special tourism villages. Rural landscape construction also receives very fast development. However, high-speed development also brings many negative effects. Because in rural tourism, rural landscape lacks planning and guidance and the idea of villagers exists deviation, it leads to the situation that the quality of many rural tourism landscapes is not high and the contents tend to be the same. It not only destroys the original beautiful landscape, but also wastes the limited capital and land. In general, rural tourism landscape mainly has the following problems:

\section{A. Rural Tourism Landscape Generally Lacks Integrated Planning}

The landscape layouts in many sightseeing places are chaotic and lacks theme; some scenic spots combine a variety of landscape elements, which causes visual restlessness; some rural tourism lacks organic connection with traditional tourist attractions with poor symbiosis.

\section{B. In Development Process, Many Villages Gradually Lose Local Characteristics}

The original landscape and integrity of historical resources are gradually destroyed. The function of inheriting the history gradually disappears. The problem of urbanization of the countryside is increasingly prominent, seriously influencing sightseeing and experience of tourists.

\section{The Landscape Is Disordered, with Farraginous Style}

Village construction neglects coordination of traditional scene and natural landscape of villages. The later-stage maintenance of landscape is inadequate, causing environmental destruction and wasting of resources; the building type of each household is different and the style is chaotic. The external walls of houses do not have any trace of design.

\section{The Depth of Tourism Products Is Not Excavated Enough and the Intention of Landscape Is Not Very Clear}

Most rural tourism development focuses on product types of sightseeing agriculture and leisure agriculture. The products are the same. Most of them lack characteristics and tourism projects with strong participation that are carried out by combining rural unique folk custom. It is impossible to let tourists truly experience interestingness of country life, without enough appeal.

\section{E. Landscape Infrastructure Is Not Perfect}

The cleanness of rural environment is not sound. The drainage outlets are blocked. The sanitary conditions of restaurants, kitchens and toilets are not good. The intensity to improve the environment is inadequate, lacking necessary sewage treatment system, hazard-free treatment system of household garbage and supporting facilities such as fire fighting, transportation, parking, electricity utilization and indication board.

\section{PlanNing AND DESIGN Of RURAL TOURISM LANDSCAPE}

\section{A. Rural Architecture Design}

At present, the rural architecture design can be roughly divided into two main forms, namely repair and of old architecture and new construction. For existing old architectures in villages, many are relatively old and have a long history. The planning layout is also unreasonable. It is suitable to properly repair corresponding architectures under the overall landscape planning, increase greening around the architecture to buffer the discordance of house layout. Houses with big visual interference can be torn down. In planning and design, we should strengthen the protection and repair of architecture of ancient sites and traditional characteristics dwellings which centrally reflect local characteristics and local culture.

With the development of the times, a large number of new buildings are built in villages to meet actual demands of modern people. For newly-built buildings, the design and construction should keep countryside features, highlight rural life, respect historical context, and integrate with surrounding environment and landform to form harmonious and unified village landscape with beautiful environment.

\section{B. Courtyard Landscape Space Design in Villages}

Courtyard is the place for daily life of villagers. In rural tourism, it is also the place for tourist lodging of travelers. It makes the form of courtyards in villages different from the pattern of urban gardening and becomes the place that integrates traditional custom, production and living habit with modern pace of life. The courtyard can be designed into the place with a number of purposes such as production, living, dining, leisure, storage and airing.

In courtyard greening, local varieties of trees that are easy to survive and grow should be selected. Use rich plant species to keep the courtyard green at all seasons. In planning and design, take the need for day lighting into full consideration, 
make the courtyard green, beautiful, colorful, fragrant and idyllic to embody leisurely and comfortable atmosphere of the courtyard, plant productive fruit trees such as grape, pomegranate and cherry in combination with garden trees, which has viewing function. Efficient organization of courtyard planting can get healthy food, meet living needs of residents in villages and beautify the courtyard.

\section{Road Landscape Space Design}

Convenient transportation is the important factor for successful operation of rural tourism as well as important link of rural landscape design. The transportation construction of rural tourism should ensure tourists can travel freely and smoothly and guarantee the consistency of transportation corridor, surrounding buildings and vegetation structure. Indication boards should be set at road intersections in the village and resting place beside the road. Electric wires along the streets and communication lines present an ugly appearance and it is encouraged to bury them under the ground. Under the circumstance of meeting the requirements of transportation, base on conditions on both sides of the road, set shade trees, flower bed, small pieces of green space and small parks to embody new image of villages. The road greening adopts indigenous plants with local characteristics and extensive type of management style, full of delight in the wild. All in all, comparatively perfect, integrated and delicate design for roads and surrounding space can bring beautiful, comfortable and unforgettable experience for tourists.

\section{Water System Landscape Space Construction}

Water landscape in rural tourist area includes natural water areas such as creeks, rivers and lakes flowing through the village, and productive artificial water body such as ponds and reservoirs. Rural water body design should integrate with landform and plants to create landscape. Firstly, base on the principle of safety first, equip lamps and lanterns as well as environment sanitation facilities, form beautiful ecological landscape, fully show natural style and protect the water body from being polluted.

On one hand, the landscape water system construction should dredge and renovate watercourse, recover ecological environment of watercourse, combine with forest belts and characteristic residential buildings on both sides, integrate natural running water with artificial landscape through the conception of conforming to nature, embody organic combination of nature, ecology, history and culture as well as humanization; on the other hand, water system landscape can integrate local features and leisure experience function. For example, small ponds are transformed into ornamental pond, fishpond and wading pool for people to enjoy the sight, go angling, play and have a rest; irrigation canals and ditches as well as reservoirs can provide places for tourists to take a rest and enjoy the sight on the basis of design of plants and waterborne platforms. Therefore, it can develop industry and strengthen the interaction between human and nature, achieve the aim to comprehensively make use of natural water resources.

\section{E. Rural Plant Configuration Design}

Plants are the basis of ecological construction and rural landscape planning and play an extremely important role in landscape. In addition, plants are the principal element to embody the nature and the basis to create rural landscape and rural ecological system. Ornamental flowers and trees are often planted along rivers, roads, villages and in front of buildings in rural tourist area; big shade trees are planted behind buildings in general. Courtyard greening often chooses indigenous tree species that are easy to survive and grow. Plant productive fruit trees in combination with garden trees, which have ornamental and economic functions. Besides, we should also fully consider characteristics of different kinds of plants, such as ornamental value, flowering phase, fruiting season and habitual nature, seasonality of sightseeing and maintenance cost, determine the selection of vegetation type and later-stage implementation. The arrangement of plants should realize that there are sceneries at all seasons and each season is different. The transpositional plants landscape can remind villager the change of solar terms and the period for labor. All in all, in configuration design of plants in the countryside, it is necessary to fully consider all kinds of factors and needs, and then construct rural environment into green, leisurely, comfortable and colorful space.

\section{F. Rural Environmental Facilities Design}

1) Public toilet: Setting public toilet in rural tourism place is a very important link. At the present stage, toilets in the countryside are mainly located in courtyards of villagers and have weak sanitary condition. In planning and design, pay attention to adopting local building materials and modeling and sanitary disposal of toilets. Public toilets should be set at places near the entrance of villages and important functional area for tourists to use. Toilets in villages should combine with plant greening. It should be covert but have clear indication board. If condition permits, choose environmentally friendly toilets and combine with production of villagers to carry out recycling of wastes.

2) Dustbin design: Generally speaking, there are few dustbins in villages, but after rural tourism is carried out, tourists will bring large quantities of household garbage, so it is very necessary to set dustbins. It shall meet using function as well as conform to requirements of landscape aesthetics in design. It should be built in places for people to gather and rest. In addition, the toilets should be designed into solid and practical type. The modeling should coordinate with local style. It can use the form of life utensils with local characteristics in villages or interesting images.

3) Seating design: Seats are necessary facilities for people to tour and take a rest. The modeling, texture and color of seats should be designed on the basis of rural environment. Seats should be set along both sides of the road or within range of visibility of tourists in scenic spots, convenient for people to enjoy the sight. The materials of seats should be local materials such as wood and stone.

4) Lighting: The lighting in the evening of rural tourism places should not be brightly-lit as cities but embody the tranquility of evening in the countryside. Set street lamps 
along main roads. The forms of lamps should be designed by looking for inspiration from local landscape images. Floor lamps should be set at places where the terrain changes or dangerous sites to remind people of the possible danger. Implement key design in important activity sites, increase illumination and promote vitality at night in the countryside.

5) Advertisement and indication board: Advertisement and indication board at rural tourism places should be designed uniformly. Give instructional design guideline on location, scale, color and font on buildings. The design should embody local characteristics. The advertising forms should adopt forms such as word sign and horizontal inscribed board and form atmosphere with unique features in the countryside.

\section{CONCLUSION}

Rural landscape is the core of rural tourism construction. The quality of its planning will directly influence harmonious coexistence between human and nature as well as sustainable development of rural tourism. Reasonably developing rural tourism is the important measure to adjust rural industrial structure, settle surplus rural labor force and promote construction of socialism new countryside. Planning, renovation and design of landscape environment can effectively make use of rural tourism resources, protect countryside culture, strengthen appeal of rural tourism, promote common development and progress of the country and society, and then realize sustainable development of rural tourism and harmonious coexistence between human and nature.

\section{REFERENCES}

[1] Wang Yuncai, Guo Huancheng, Xu Huilin. Principles and Methods of Rural Tourism Planning, Beijing: Science and Technology Publishing House, 2006: 32-35.

[2] Xiao Shenghe. Research on Tourism Landscape Planning in Baihe Village, Fuyang, Hangzhou, Journal of Fujian Forestry Science and Technology, 2007, (4): 206-209.

[3] Xu Liping. Research on Vernacular Architecture Landscape Construction in Rural Tourism Landscape of Fujian Province, Fujian Agriculture and Forestry University, 2009.

[4] Yang Peng. Research on Tourism Landscape Planning and Design in Villages of Suburbs of Large Cities, Beijing University of Technology, 2009. 